\title{
Kazimierz Ożóg, Polszczyzna przełomu XX i XXI wieku. Wybrane zagadnienia, Rzeszów 2001, s. 263
}

Wykorzystana literatura i własne doświadczenia badawcze Kazimierza Ożoga, a także data publikacji przekonują, że wbrew zapowiedzi zawartej w tytule, interesująca i ważna książka rzeszowskiego językoznawcy tylko w nieznacznym stopniu traktuje o polszczyźnie przełomu XX i XXI wieku. W istocie bowiem, co lojalnie przyznaje sam autor we Wprowadzeniu, „wpisuje się w bogaty nurt rozważań językoznawczych nad językiem polskim lat osiemdziesiątych i dziewięćdziesiątych minionego stulecia" ${ }^{1}$. Można odnieść wrażenie, że głównym powodem tego nieco sztucznego poszerzenia perspektywy czasowej była chęć uniknięcia kolizji z tytułem książki Andrzeja Markowskiego Polszczyzna końca $X X$ wieku², której zasięg czasowy wyznacza koniec nie wieku, lecz lat osiemdziesiątych. Ta lapidarna konfrontacja pozwala dojść do wniosku, że opracowania A. Markowskiego i K. Ożoga to swoiste rozdziały większego dzieła poświęconego polszczyźnie ostatniej ćwierci wieku XX. Dzieła, w którym cezurę stanowi rok 1989. Inna rzecz, że o ile A. Markowski o tym punkcie granicznym w ogóle nie wspomina (zapewne dlatego, że właśnie $\mathrm{w}$ tym czasie trwał proces produkcji książki), to dla K. Ożoga data ta otwiera zupełnie nową epokę w najnowszych dziejach polszczyzny. Nawiasem mówiąc, porównanie tych dwóch pu-

\footnotetext{
1 Por. przede wszystkim: Wspótczesny język polski, red. J. Bartmiński, Wrocław 1993, Polszczyzna $i$ Polacy u schyłku XX wieku, red. K. Handke, H. Dalewska-Greń, Warszawa 1994, Wspótczesna polszczyzna mówiona $w$ odmianie opracowanej (oficjalnej), red. Z. Kurzowa, W. Sliwiński, Kraków 1994, Polszczyzna 2000. Orędzie o stanie języka na przełomie tysiąclecie, red. W. Pisarek, Kraków 1999, Język $w$ mediach masowych, red. J. Bralczyk, K. Mosiołek-Kłosińska, Warszawa 2000, Stownictwo wspótczesnej polszczyzny w okresie przemian, red. J. Mazur, Lublin 2000, Polszczyzna XX wieku. Ewolucja i perspektywy rozwoju, red. S. Dubisz, S. Gajda, Warszawa 2001, Przyszłość języka, red. S. Krzemień-Ojak, B. Nowowiejski, Białystok 2001.

2 Warszawa 1992.
} 
blikacji tak przecież $\mathrm{w}$ czasie nieodległych, unaocznia jak dalece zmienił się język polski w ciągu tylko jednego dziesięciolecia, jak ogromnie zróżnicowana jest materia języka, jak liczne jego uwarunkowania, wreszcie, jak odmiennie można tę mozaikę zjawisk i tendencji postrzegać i opisywać.

$\mathrm{W}$ świetle opracowań, które przedstawiają sytuację i kształt języka polskiego końca XX i początków XXI wieku książka K. Ożoga zajmuje miejsce szczególne. Jest $\mathrm{w}$ zasadzie jedynym, od czasu książki A. Markowskiego, opracowaniem indywidualnym, pozostałe publikacje są rezultatem dociekań wielu autorów. Kilkakrotnie K. Ożóg podkreśla, że jego dzieło nie ma wyłącznie charakteru teoretycznej refleksji, lecz jest przede wszystkim opracowaniem materiałowym. Stąd wszelkie obserwacje i wnioski są uwarunkowane jakością poddawanego analizie bogatego materiału językowego (s. 6-7). O specyfice książki mówi też podtytuł Wybrane zagadnienia. Nie jest to więc klasyczna monografia, w tym sensie że składa się na nią seria artykułów odpowiednio przeredagowanych, tak by mogły stanowić rozdziały książki (s. 9). Nie dziwi więc, że autor nie rości sobie pretensji do tego, by uważać jego dzieło za kompletne, całościowo omawiające i wyczerpujące problematykę.

Na recenzowaną książkę składa się, poza syntetycznymi uwagami wstępnymi i lapidarnym zakończeniem, dwanaście rozdziałów o różnej objętości, omawiających zagadnienia różne co do charakteru i doniosłości. K. Ożóg dokonuje szczególnego wyboru omawianych kwestii, koncentruje się nie tylko na tym, co dla funkcjonowania polszczyzny w ostatnich latach istotne i nowe, ale też na tych kwestiach, które są przedmiotem jego badawczych zainteresowań, jak zagadnienia języka polityki i reklamy, przeobrażenia mowy wsi czy sprawy językowej grzeczności.

Szczególny charakter ma rozdział pierwszy, w którym Ożóg przedstawia społeczno-polityczne, ekonomiczne i kulturalne uwarunkowania rozwoju języka polskiego $\mathrm{w}$. ostatnich dwudziestu latach oraz szkicowo przedstawia najważniejsze zjawiska. Ten rozdział nie tylko zapowiada problematykę całego opracowania, ale też jego specyficzną kompozycję. Uwidacznia się w niej doświadczenie dydaktyczne autora i przywiązanie do podręcznikowego układu treści. Najpierw, w ogólnym zarysie, 
otrzymujemy zapowiedź, co jest przedmiotem kolejnych rozdziałów, by po szczegółowym rozwinięciu kolejnych zagadnień, całość na zakończenie rozdziału syntetycznie podsumować. To rozwiązanie, choć znakomicie ułatwia lekturę, sprawia że całość jest przejrzysta i czytelna, i może nawet przesądza o praktycznym wykorzystaniu książki, to ma też konsekwencje mniej pozytywne, prowadzi czasem do zbędnych powtórzeń.

Jak wielu innych autorów zajmujących się zagadnieniami współczesnej polszczyzny, K. Ożóg dostrzega zależność tych zmian przede wszystkim od czynników zewnętrznych ${ }^{3}$ : politycznych, społecznych i ekonomicznych. Zarazem nie docenia chyba atrakcyjności i siły oddziaływania środków masowego przekazu, skoro przypisuje im znaczenie drugorzędne (s. 16). Z tą opinią kontrastują wypowiedzi innych badaczy, np. I. Bajerowej, która wręcz proponuje uznać najnowszą dobę rozwoju polszczyzny za epokę medialną ${ }^{4}$, czy H. Jadackiej upatrującej przemożny wpływ mediów na liberalizację polskiej normy językowej ${ }^{5}$. K. Ożóg w zakończeniu pracy łagodzi nieco wymowę swego stwierdzenia, zaliczając jednym tchem uwarunkowania społeczno-polityczne i media do podstawowych czynników sprawczych rozwoju polszczyzny. Tym sposobem usuwa obecną w prowadzonych rozważaniach niekonsekwencję, sam bowiem wielokrotnie $\mathrm{w}$ tekście książki podkreśla niezwykle istotny wpływ mediów na sferę języka, zwłaszcza na język polityki, polską grzeczność językową i socjolekt młodzieżowy.

Wielkim atutem pracy K. Ożoga jest to, że bada język polski i jego odmiany w kontekście zmian cywilizacyjnych, w ścisłym powiązaniu z tendencjami współczesnej kultury (s. 6). Poszukując źródeł i uwarunkowań zmian w planie językowym, bierze pod uwagę w pierwszej kolejności procesy dziejące się $\mathrm{w}$ przestrzeni kulturowej. Zalicza do nich,

3 Por. I. Bajerowa, Zarys historii języka polskiego 1939-2000, Warszawa 2003, B. Dunaj, O stanie wspótczesnej polszczyzny, w: Język trzeciego tysiaclecia, red. G. Szpila, Kraków 2000, s. 25-26, J. Mazur, Tendencje rozwojowe wspótczesnego języka polskiego, „Annales UMCS”, Lublin 2000.

4 I. Bajerowa, s. 158.

5 Por. Wptyw mediów na złagodzenie kryteriów poprawności stowotwórczej, w: Polszczyzna w komunikowaniu publicznym, red. J. Bralczyk, W. Gruszczyński, G. Majkowska, Warszawa 1999, s. 27-36. 
za S. Gajdą, demokratyzację, marketyzację i technologizację ${ }^{6}$ i uzupełnia ten wykaz o szeroko rozumiany proces amerykanizacji, który wyraża się $\mathrm{w}$ zmianach postaw kulturowych, a następnie zachowań językowych Polaków. Co więcej, nie tylko postrzega ten proces jako główny przejaw tendencji globalizacyjnych, których podłożem jest konsumeryzm (s. 225-228), ale też wyraża obawę, że w przyszłości doprowadzi on do obniżenia rangi polszczyzny (s. 46).

Do najważniejszych zjawisk wywołanych głównie przez demokratyzację języka i tolerancję wobec swobody wypowiadania się, ale też ze zrodzonej z tendencji postmodernistycznych - intertekstualności, zalicza autor przede wszystkim ekspansję modnej, bo dowartościowanej i nobilitowanej potoczności. Jej nasiloną obecność obserwujemy w polszczyźnie oficjalnej: w tekstach wyborczych, sloganach reklamowych i nagłówkach prasowych, a nawet języku religijnym. Paradoksalnie, liczne kolokwializmy leksykalne i frazeologiczne, potoczna metaforyka militarna i sportowa, nieustanna gra słowem, które w zamierzeniu autorów tekstów politycznych i reklamowych powinny być źródłem ekspresji i świeżości, na skutek ciągłego powtarzania, prowadzą w rezultacie do tworzenia nowych szablonów i stylistycznej monotonii. $Z$ awansem potoczności nierozłącznie wiąże się wulgaryzacja i brutalizacja języka, upowszechnianie negatywnych wzorców językowych oraz uproszczenie polskiej etykiety grzecznościowej.

Wpływem języka ogólnego, w tym zwłaszcza jego odmiany potocznej, tłumaczy K. Ożóg nasilony proces zanikania polskich gwar ludowych w ich czystej postaci. Potwierdza zatem spostrzeżenia A. Wilkonia7, że w drugiej połowie XX wieku, dominują w polskim pejzażu językowym odmiany mieszane. W kontekście potrzebnych i interesujących uwag o języku mieszkańców wsi daje się dotkliwie odczuć brak, chociaż krótkiego komentarza, do ważkich procesów zachodzących obecnie w języku polskich miast ${ }^{8}$.

\footnotetext{
6 Wspótczesna polska rzeczywistość językowa i jej hadanie, w: Mowa rozświetlona myśla, red. J. Miodek, s. 12.

7 Por. Typologia odmian językowych wspótczesnej polszczyzny, Katowice 2000, s. 25-26.

8 Sporo ciekawych spostrzeżeń na ten temat przyniosła ogólnopolska konferencja „Polszczyzna miejska. Metodologia badań", która odbyła się w dniach 15-16 września 2003, w Instytucie Filologii Polskiej Uniwersytetu w Białymstoku (materiały konferencyjne w druku).
} 
Istotne zmiany mają miejsce we współczesnym języku polityki. Poza kolokwializacją oraz coraz liczniejszymi zapożyczeniami i oryginalnymi wtrętami $z$ języków obcych, zwraca uwagę nasilona perswazyjność, którą uzyskuje się przez nieustanne wartościowanie i zabiegi retoryczne. Nie jest zaskoczeniem, że podobne zjawiska dają się zauważyć $w$ tekstach reklamowych. Tu jednakże podstawę perswazyjności stanowią określone kategorie semantyczne, zwłaszcza nowość i nowoczesność, tradycja i związek z naturą. Pewne zdziwienie może budzić fakt, że pod względem nasycenia wartościami teksty polityczne są bliskie nie tylko sloganom reklamowym, ale też niektórym tekstom kościelnych kazań (s. 175).

Oryginalnym pomysłem, aczkolwiek zachęcającym do dyskusji, jest wyróżnienie nowych odmian języka polskiego, mianowicie stylu reklamowego i komputerowego, zwanego w zakończeniu stylem komputerów $i$ internetu (s. 240). Zdaniem autora, do uznania, że w tekstach reklamowych mamy do czynienia $\mathrm{z}$ funkcjonowaniem odrębnego stylu wystarczy przyznanie, że charakteryzują się one swoistym wyborem środków językowych i ich konfiguracją oraz szczególną organizacją tekstu (s. 103). Z kolei, za cechy konstytutywne stylu komputerowego uznaje autor liczne terminy specjalistyczne oraz widoczną tendencję do skrótu, a także liczne zapożyczenia i kolokwializmy. Problem w tym, że te właściwości można dziś odnaleźć niemal w każdej odmianie języka ogólnego i socjolektach. Być może zatem należałoby mówić nie o stylu, lecz o terminologii komputerowej czy informatycznej. Całą sprawę dodatkowo komplikują dwie uwagi, jedna - o szerzeniu się internetowej nowomowy (s. 233-234), druga, o języku poczty elektronicznej (s. 38). Szkoda, że w żadnym miejscu autor nie tłumaczy, jak mają się te językowe byty do wyróżnionego stylu komputerowego (komputerów).

W oscylowaniu socjolektu młodzieży między dwoma podstawowymi kodami: ograniczonym i nieograniczonym K. Ożóg dostrzega tendencję do wzmacniania kodu ograniczonego, co tłumaczy wpływem mediów, amerykańską modą na luz i dominacją chęci posiadania dóbr. Zachęca jednak do polemiki, konstatując, bez słowa wyjaśnienia, że środowiskowa odmiana funkcjonuje niemal wyłącznie na poziomie szkoły, zaś studenci usuwają ze swojego języka elementy socjolektalne (s. 194). 
Za ogromnie ważne dla stanu języka polskiego w ostatnim dziesięcioleciu uznaje autor wejście Polski w uniwersalny krąg kultury konsumpcyjnej, której naczelną zasadą jest nastawienie na posiadanie dóbr materialnych i ciągłą ich konsumpcję (104). Konsekwencje tego faktu są rozmaite. W przestrzeni pozajęzykowej sprowadzają się przede wszystkim do jej reifikacji i zjawiska hiperkonsumpcji. W sferze języka natomiast przejawia się $\mathrm{w}$ gwałtownym rozrastaniu się warstwy chrematonimów i intensywnej apelatywizacji firmowych nazw własnych. Najważniejszym skutkiem jest jednak ukształtowanie się zupełnie nowej odmiany języka, mianowicie polszczyzny konsumpcyjnej, którą autor utożsamia $\mathrm{z}$, typową dla konsumpcjonizmu, postawą mieć (s. 214).

Praca K. Ożoga pokazuje dynamiczny obraz ważkich zmian dokonujących się w polszczyźnie końca XX wieku. $Z$ dotychczasowych uwag wynikać jednak może, że rzecz dotyczy wyłącznie odmian języka polskiego, ich obecnego stanu i dziejących się przeobrażeń, zaniku starych i rodzenia się nowych. W istocie, równie wiele miejsca poświęca autor zjawiskom występującym w warstwie słownikowej. Co więcej, nie polega to wyłącznie na wykorzystaniu leksyki jako podstawy materiałowej dla prowadzonych rozważań. Autor wręcz podkreśla, że najbardziej znaczące zmiany zaszły w ostatnim dwudziestoleciu w systemie leksykalnym polszczyzny (s. 26). Najbardziej tego widocznym przejawem są wzmożone zabiegi nazewnicze, powoływanie do życia tysięcy nowych jednostek za pomocą procesów słowotwórczych i semantycznych oraz zapożyczania $z$ języków obcych. W słownictwie i frazeologii, jak w zwierciadle, odbijają się wszelkie korzystne, ale głównie negatywne zjawiska, m.in. bylejakość komunikowania się widoczna w użyciu licznych słów wytrychów i wulgaryzmów, uleganie konsumpcyjnemu modelowi życia, kierowanie się modą i wygodą $\mathrm{w}$ tworzeniu i doborze środków leksykalnych. W konsekwencji, przy rosnącej liczbie niepożądanych jednostek słownikowych pogłębia się ubóstwo słownikowe Polaków, upraszcza i prymitywizuje styl wypowiedzi, powstają nowe bariery utrudniające porozumienie.

Wnikliwe spojrzenie na współczesny język polski z perspektywy uwarunkowań społeczno-politycznych, ekonomicznych i kulturowych, zwłaszcza z uwzględnieniem unifikujących tendencji globalizacyjnych pozwala autorowi, a w konsekwencji i czytelnikowi, wyrobić sobie wy- 
raźny pogląd na kształt i funkcjonowanie obecnej polszczyzny. Wiele tych zmian i procesów ma charakter niekorzystny. Jednak konkluzja K. Ożoga nie ma wymowy katastroficznej. Językoznawca trzeźwo ocenia stan naszego języka, jest przekonany, że mimo dających się zauważyć wielu negatywnych zjawisk: „język polski jest dziś dobrze rozwiniętym językiem narodowym, znakomicie zaspokajającym potrzeby komunikacyjne Polaków" (s. 241). 